\title{
Are blood eosinophils a prime-time biomarker for COPD management decisions?
}

This article was published in the following Dove Press journal:

International Journal of COPD

\author{
Ioanna Tsiligianni' \\ Alan G Kaplan² \\ 'Department of Social Medicine, \\ Faculty of Medicine, University of \\ Crete, Heraklion, Greece; ${ }^{2}$ Family \\ Physician Airways Group of Canada, \\ University of Toronto, Toronto, \\ ON, Canada
}

COPD is a preventable and treatable disease with patients showing a great disease heterogeneity with respect to risk of exacerbations, symptomatology and health status. Dual bronchodilation has been suggested by the recent Global Initiative for Obstructive Lung Disease guideline as the cornerstone of treatment for COPD, limiting the value of inhaled corticosteroids (ICS) only for patients exacerbating on dual bronchodilators or possibly in those with frequent exacerbations. ${ }^{1}$ Elevated blood eosinophil count has been suggested as a useful biomarker to guide treatment decisions as its finding is considered consistent with a good ICS response to treatment, ${ }^{2-4}$ although this has been questioned in a recent post hoc analysis of the FLAME study. ${ }^{5}$ The practicing physician wants a biomarker to assess the risk of exacerbations and guide treatment accordingly; are blood eosinophils the answer?

It is important to recognize that we are discussing patients with COPD and without asthma whose blood eosinophil count is less than 600 , as it was in the FLAME study. ${ }^{6}$ Patients with very high blood eosinophils should be looked at differently (perhaps as if they have a component of asthma), albeit they were not in the exclusion criterion in older trials such as WISDOM $(>95 \%$ of patients had a blood eos <600), ${ }^{7}$ ISOLDE, $^{8}$ INSPIRE $^{9}$ or in a meta-analysis of some of previous studies of budesonide/formoterol. ${ }^{10}$ In COPD studies wherein asthma was excluded, a blood eosinophil cutoff level of $2 \%$ has been proposed as this shows high sensitivity for predicting sputum eosinophilia. ${ }^{11}$ Elevation of sputum eosinophils has shown predictability as a marker of ICS response which has led to the interest in using blood eosinophil count as a surrogate measurement. However, despite this being biologically plausible, the evidence of the consistency of blood with sputum/tissue eosinophils is conflicting. Negewo et al showed that blood eosinophils can help identify the presence or absence of sputum eosinophils, ${ }^{12}$ while Turato et al study showed that blood eosinophilia does not reflect tissue eosinophils. ${ }^{13}$ However, sputum eosinophil count $>3 \%$ is observed in up to $28 \%$ of cases with acute exacerbations. ${ }^{11}$ The studies by Negewo et a ${ }^{12}$ and Bafadhel study ${ }^{10}$ showed a eosinophil count of more than $2 \%$ in blood served as a biomarker of eosinophil count of $>3 \%$ in sputum, and $40 \%$ of patients showed a discordance between sputum and blood at the blood eosinophil cutoff point of $0.3 \times 10^{9} /$ L. $^{11,12}$ Therefore, there remains significant doubt as to whether blood eosinophils actually depict tissue and sputum eosinophils.

The Copenhagen Lung Study was recently reviewed, and the results showed an increase in exacerbations when blood eosinophilia count was above $0.34 .{ }^{14}$ Conversely, a meta-analysis by Ho et al which included 14 observational and randomized controlled (oanna Tsiligian Department of Social Medicine, Faculty Universine, University of Crete, Voute

Crete, Greece

Tel +3028I0 394706

Fax +302810394621

Email i.tsiligianni@uoc.gr
International Journal of COPD 2018:13 |889-189| Dovepress if in 0 (c) (1) (-) 2018 Tsiligianni and Kaplan. This work is published and licensed by Dove Medical Press Limited. The full terms of this license are available at https://www.dovepress.com/terms.php hereby accept the Terms. Non-commercial uses of the work are permitted without any furcther (unported, v3.0) License (http://creativecommons.org/licenses/by-nc/3.0/). By accessing the work you hereby accept the Terms. Non-commercial uses of the work are permitted without any further permission from Dove Medie
for commercial use of this work, please see paragraphs 4.2 and 5 of our Terms (https://www.dovepress.com/terms.php). 
trials with parallel groups comparing COPD patients with an elevated blood eosinophil count defined as having more than $2 \%$ of eosinophils, either in the blood or sputum, revealed a similar risk of both exacerbation at 12 months and in-hospital mortality with or without elevated blood eosinophil. ${ }^{15}$

Moreover, a recent study by Casanova et al using data from the CHAIN and BODE cohort showed that exacerbation rates did not differ in patients with and without eosinophil counts above 300 cells $/ \mu \mathrm{L}^{16}$ consistent with the ECLISPE study. ${ }^{17}$ Zysman et al reported that for all cutoffs, 2\% versus $<2 \%, \geq 3 \%$ versus $<3 \%$, and $\geq 4 \%$ versus $<4 \%$, there was no difference between Eos+ and Eos- groups in exacerbation rate, history of asthma, or three-year survival. ${ }^{18}$

Eosinophils are not stable throughout the life of a patient with COPD, ${ }^{17,19}$ and it has also been reported that blood eosinophil counts vary within the same person at different times of day and on different days even in healthy subjects. ${ }^{20}$ This lack of stability could result in the blood eosinophil not being a reliable biomarker.

A biomarker is only useful if it could be used to assist in disease management. Many studies have suggested ICS in patients with elevated blood eosinophil count defined as $>2 \%$ of total white cells or of a total eosinophils of $>300$ cells $/ \mu \mathrm{L} .{ }^{2-4}$ However in most of these studies, the ICS were used in combination with a long-acting beta-agonist (LABA) ${ }^{3,4} \mathrm{~A}$ recent post hoc analysis showed that level of eosinophils may also be correlated with the response to bronchodilators. ${ }^{21}$ Similarly, a post hoc analysis of the FLAME study tested several blood eosinophil cutoff levels and found that there was no cutoff level to show the ICS-containing salmeterol/fluticasone to be superior to indacaterol/glycopyrronium (IND/GLY) (ie, LABA/long-acting muscarinic-agonist [LAMA] with no ICS) in terms of reduction in moderate/severe exacerbation rate or time to first exacerbation. ${ }^{5}$ This study did suggest that because IND/GLY is always superior in patients with low blood eosinophils but of similar efficacy in the groups with high eosinophil level, blood eosinophils may have a role in identifying patients who benefit from ICS in addition to LABA/LAMA. ${ }^{5}$

Elevated blood eosinophil counts are associated with a wide variety of allergic, rheumatologic, infectious, neoplastic, and rare idiopathic disorders. ${ }^{22}$ There are many therapies that can raise eosinophil counts, including medications, nutritional supplements, and alternative therapies. ${ }^{22,23} \mathrm{COPD}$ patients are multi-morbid and require many non-respiratory treatments. ${ }^{24}$ Many commonly prescribed drugs such as amphetamines (used as appetite suppressants), antibiotics (penicillins, cephalosporins, and sulfonamides), NSAIDs, ranitidine, allopurinol, antirheumatics, anticonvulsants, aspirin, and tranquilizers can cause elevated eosinophil counts..$^{22,23} \mathrm{On}$ the other hand, the use of systemic steroids can decrease eosinophil counts. Therefore, in order for the clinician to use the blood eosinophil as a biomarker, a complete medication history including over-the-counter medications, supplements, herbal preparations, and vitamins is necessary. ${ }^{22,23}$ Future studies also need to take this into consideration.

While we have been discussing the measurement of blood eosinophils as a percentage of the total white blood cell counts, most hematology evaluations and treatments are done based on an absolute count. For instance, in the evaluation of febrile neutropenia, the absolute neutrophil count is what is used to drive treatment decisions. ${ }^{25}$ The absolute eosinophil count refers to the number of circulating eosinophils in the peripheral blood (in cells $/ \mu \mathrm{L}$ ). It is determined by multiplying the total white blood cell count by the percentage of eosinophils. Eosinophil counts are reported differently around the world, and the clinician may need to calculate the eosinophil count prior to its use.

Conclusively, while it is exciting to postulate that the blood eosinophils could be an easily available biomarker to guide the treatment of COPD, in particular to predict the response to ICS, there are some potential barriers to their use. These include comorbidities, current medications and treatments, the extra efforts needed to calculate the eosinophil level, the inconsistency of blood eosinophils with sputum and tissue eosinophils, the relationship with recent exacerbations, the instability in the level of blood eosinophils within the same patient at different times of day, and the conditions and effect of current or recent steroid treatment. Perhaps, we need to recognize that there is a limitation to this biomarker and tread cautiously in recommending its use.

\section{Disclosure}

Prof Ioanna Tsiligianni has been an advisory board member or speakers bureau member for AstraZeneca, Boehringer Ingelheim, GSK, and Novartis. Dr Alan Kaplan has been an advisory board member or speakers bureau member for AstraZeneca, Benton Dickinson, Boehringer Ingelheim, Grifols, GSK, Johnson \& Johnson, Mylan, Novo Nordisk, Purdue, Novartis, Trudel, Paladin, and Sanofi. The authors report no other conflicts of interest in this work.

\section{References}

1. Global Strategy for the Diagnosis, Management and Prevention of COPD (homepage on the Internet). Global Initiative for Chronic Obstructive Lung Disease (GOLD). 2018. Available from: http://goldcopd.org. Accessed May 5, 2018. 
2. Calverley PM, Tetzlaff K, Vogelmeier C, et al. Eosinophilia, frequent exacerbations, and steroid response in chronic obstructive pulmonary disease. Am J Respir Crit Care Med. 2017;196(9):1219-1221.

3. Pavord ID, Lettis S, Locantore N, et al. Blood eosinophils and inhaled corticosteroid/long-acting $\beta$-2 agonist efficacy in COPD. Thorax. 2016; 71(2):118-125.

4. Pascoe S, Locantore N, Dransfield MT, Barnes NC, Pavord ID. Blood eosinophil counts, exacerbations, and response to the addition of inhaled fluticasone furoate to vilanterol in patients with chronic obstructive pulmonary disease: a secondary analysis of data from two parallel randomised controlled trials. Lancet Respir Med. 2015;3(6):435-442.

5. Papi A, Kostikas K, Wedzicha JA, et al. Dual bronchodilation response by exacerbation history and eosinophilia in the FLAME study. Am J Respir Crit Care Med. Epub 2017 Nov 3.

6. Wedzicha JA, Banerji D, Chapman KR, et al; FLAME Investigators. Indacaterol-glycopyrronium versus salmeterol-fluticasone for COPD. N Engl J Med. 2016;374(23):2222-2234.

7. Magnussen H, Disse B, Rodriguez-Roisin R, et al; WISDOM Investigators. Withdrawal of inhaled glucocorticoids and exacerbations of COPD. N Engl J Med. 2014;371(14):1285-1294.

8. Burge PS, Calverley PM, Jones PW, Spencer S, Anderson JA, Maslen TK. Randomised, double blind, placebo controlled study of fluticasone propionate in patients with moderate to severe chronic obstructive pulmonary disease: the ISOLDE trial. BMJ. 2000;320(7245):1297-1303.

9. Wedzicha JA, Calverley PM, Seemungal TA, et al; INSPIRE Investigators. The prevention of chronic obstructive pulmonary disease exacerbations by salmeterol/fluticasone propionate or tiotropium bromide. Am J Respir Crit Care Med. 2008;177(1):19-26.

10. Bafadhel M, Peterson S, De Blas MA, et al. Predictors of exacerbation risk and response to budesonide in patients with chronic obstructive pulmonary disease: a post-hoc analysis of three randomised trials. Lancet Respir Med. 2018;6(2):117-126.

11. Bafadhel M, McKenna S, Terry S, et al. Acute exacerbations of chronic obstructive pulmonary disease: identification of biologic clusters and their biomarkers. Am J Respir Crit Care Med. 2011;184(6):662-671.

12. Negewo NA, McDonald VM, Baines KJ, et al. Peripheral blood eosinophils: a surrogate marker for airway eosinophilia in stable COPD. Int J Chron Obstruct Pulmon Dis. 2016;11:1495-1504.

13. Turato G, Semenzato U, Bazzan E, et al. Blood eosinophilia does not reflect tissue eosinophils nor worsen clinical outcomes in COPD. Am J Respir Crit Care Med. Epub 2017 Oct 16.
14. Vedel-Krogh S, Nielsen SF, Lange P, Vestbo J, Nordestgaard BG. Blood eosinophils and exacerbations in chronic obstructive pulmonary disease. The Copenhagen General Population Study. Am J Respir Crit Care Med. 2016;193(9):965-974.

15. Ho J, He W, Chan MTV, et al. Eosinophilia and clinical outcome of chronic obstructive pulmonary disease: a meta-analysis. Prevalence of persistent blood eosinophilia: relation to outcomes in patients with COPD. Sci Rep. 2017;7(1):13451.

16. Casanova C, Celli BR, de-Torres JP, et al. Prevalence of persistent blood eosinophilia: relation to outcomes in patients with COPD. Eur Respir J. 2017;50(5):pii:1701162.

17. Singh D, Kolsum U, Brightling CE, Locantore N, Agusti A, Tal-Singer R; ECLIPSE Investigators. Eosinophilic inflammation in COPD: prevalence and clinical characteristics. Eur Respir J. 2014;44(6):1697-1700.

18. Zysman M, Deslee G, Caillaud D, et al. Relationship between blood eosinophils, clinical characteristics, and mortality in patients with COPD. Int J Chron Obstruct Pulmon Dis. 2017;12:1819-1824.

19. Oshagbemi OA, Burden AM, Braeken DCW, et al. Stability of blood eosinophils in patients with chronic obstructive pulmonary disease and in control subjects, and the impact of sex, age, smoking, and baseline counts. Am J Respir Crit Care Med. 2017;195(10):1402-1404.

20. Sennels HP, Jørgensen HL, Hansen AL, Goetze JP, Fahrenkrug J. Diurnal variation of hematology parameters in healthy young males: the Bispebjerg study of diurnal variations. Scand J Clin Lab Invest. 2011; 71(7):532-541.

21. Iqbal A, Barnes NC, Brooks J. Is blood eosinophil count a predictor of response to bronchodilators in chronic obstructive pulmonary disease? Results from post hoc subgroup analyses. Clin Drug Investig. 2015; 35(10):685-688.

22. Klion AD. Eosinophilia: a pragmatic approach to diagnosis and treatment. Hematology Am Soc Hematol Educ Program. 2015;2015:92-97.

23. Nutman TB. Evaluation and differential diagnosis of marked, persistent eosinophilia. Immunol Allergy Clin North Am. 2007;27(3):529-549.

24. Tsiligianni IG, Kosmas E, Van der Molen T, Tzanakis N. Managing comorbidity in COPD: a difficult task. Curr Drug Targets. 2013;14(2): $158-176$.

25. Al-Gwaiz LA, Babay HH. The diagnostic value of absolute neutrophil count, band count and morphologic changes of neutrophils in predicting bacterial infections. Med Princ Pract. 2007;16(5):344-347.

Dove Medical Press encourages responsible, free and frank academic debate. The content of the International Journal of Chronic Obstructive Pulmonary Disease 'Editorial' section does not necessarily represent the views of Dove Medical Press, its officers, agents, employees, related entities or the International Journal of Chronic Obstructive Pulmonary Disease editors. While all reasonable steps have been taken to confirm the content of each Editorial, Dove Medical Press accepts no liability in respect of the content of any Editorial, nor is it responsible for the content and accuracy of any Editorial.

International Journal of COPD

\section{Publish your work in this journal}

The International Journal of COPD is an international, peer-reviewed journal of therapeutics and pharmacology focusing on concise rapid reporting of clinical studies and reviews in COPD. Special focus is given to the pathophysiological processes underlying the disease, intervention programs, patient focused education, and self management protocols.

\section{Dovepress}

This journal is indexed on PubMed Central, MedLine and CAS. The manuscript management system is completely online and includes a very quick and fair peer-review system, which is all easy to use. Visit http://www.dovepress.com/testimonials.php to read real quotes from published authors. 